\title{
Mismatches between global, national and local red lists and their consequences for Brazilian reef fish conservation
}

\author{
M. G. Bender ${ }^{1, *}$, S. R. Floeter ${ }^{2}$, C. E. L. Ferreira ${ }^{3}$, N. Hanazaki ${ }^{2}$ \\ ${ }^{1}$ Programa de Pós-graduação em Ecologia e Conservação, UFPR, Setor de Ciências Biológicas, Curitiba, PR 81531-980, Brazil \\ ${ }^{2}$ Departamento de Ecologia e Zoologia, Universidade Federal de Santa Catarina, Edifício Fritz Müller, Florianópolis, \\ SC 88010-970, Brazil \\ ${ }^{3}$ Departamento de Biologia Marinha, Universidade Federal Fluminense, Campus do Valonguinho, \\ Niteroi, RJ 24001-970, Brazil
}

\begin{abstract}
Red lists are important tools applied worldwide to species conservation, but disagreements between lists can affect their implementation and credibility. We searched global, national and local threatened species lists for Brazilian reef fish species and compared the differences between them with respect to categories and criteria applied. Of 559 Brazilian reef fish species, 125 have been evaluated against threat criteria at different scales; a total of 43 are listed as threatened with extinction. Of 43 threatened species, 32 are mentioned in the global IUCN Red List, 11 are referred to in the national inventory, and state lists also cite 11. Six endemic species are threatened; of these, 3 are listed by the IUCN, 5 at the national level and 2 are threatened in Espírito Santo state. This highlights a mismatch between species lists: $84.8 \%$ of the species listed as globally threatened do not appear in the national list, whereas $54.5 \%$ of the species mentioned on the Brazilian list are not in the IUCN Red List. Moreover, we found disagreements in the set of categories and criteria applied in the different red listing processes. The same categories and quantitative criteria must be applied in all regional red lists, so that conservation actions are more effective and lists are trustworthy. This is imperative to attract financial support for threatened species management and recovery. Management plans must be developed for those species already listed as threatened in Brazil. In addition, a review of the national list and the inclusion of threatened Brazilian endemic fishes in the IUCN Red List are needed.
\end{abstract}

KEY WORDS: Conservation $\cdot$ Red lists $\cdot$ Reef fish $\cdot$ Threatened species

\section{INTRODUCTION}

Contemporary extinction rates and the increasing threats to ecosystems and their biodiversity have made the evaluation of species extinction risk essential for conservation planning and prioritization (Mace \& Lande 1991, IUCN 2001). In this context, the International Union for the Conservation of Nature (IUCN) provides an objective evaluation system, where species must meet quantitative criteria in order to be as- signed to Red List categories (Lamoreux et al. 2003). This quantitative evaluation system has been developed to enhance the objectivity and comparability of red lists (Mace \& Lande 1991), and has received international acceptance (Akçakaya et al. 2000, Gärdenfors et al. 2001). Moreover, the criteria and data that underlie the assumptions of the IUCN Red List have become important tools for management, monitoring and decision making worldwide (Lamoreux et al. 2003, Miller et al. 2006, Rodrigues et al. 2006). 
Nevertheless, the IUCN criteria for the evaluation of species extinction risk were developed for application at the global scale, and conservation efforts are mostly conducted at a national level. Thus, not only are national red lists important to guide these conservation actions, but appropriate criteria are also needed to evaluate the species extinction risk on such a scale (Gärdenfors 2001, Gärdenfors et al. 2001). The accuracy of national red lists is also essential because the information they contain is valuable for global-scale assessments and conservation actions (Rodríguez et al. 2000, Gärdenfors et al. 2001, Keller \& Bollmann 2004, Rodrigues et al. 2006). Thus, national-scale evaluations of species conservation status should follow a set of guidelines for regional level application (see the IUCN 'Guidelines for Application of IUCN Red List Criteria at Regional Levels'; Gärdenfors et al. 2001, IUCN 2001, 2003).

According to Brito et al. (2010), the few published studies comparing species conservation status in regional, national and global lists (Garcia \& Marini 2006, Becker \& Loyola 2008, von May et al. 2008) have already reported discrepancies between the IUCN Red List and national red lists (Hilton-Taylor et al. 2000, Rodríguez et al. 2000, von May et al. 2008). The implications of such differences include difficulties in assembling information on species conservation status in several countries (Miller et al. 2007), the undermined credibility of red listing and even species extinction (Brito et al. 2010). Studies on the current state of conservation knowledge of reef fishes are not yet available, specifically those comparing species categorization in different red lists.

In the last decade, there has been an increasing effort to understand the effects of anthropogenic pressure on reef fish communities along the Brazilian coast (Ferreira \& Gonçalves 1999, Gasparini et al. 2005, Floeter et al. 2006, Francini-Filho \& Moura 2008, Vila-Nova et al. 2011, Bender et al. 2012). Threats to Brazilian reef fishes include overfishing (Ferreira \& Gonçalves 1999, Floeter et al. 2006), bycatch (Francini-Filho \& Moura 2008) and the aquarium trade (Gasparini et al. 2005), in addition to the indirect impacts of pollution (Leão \& Dominguez 2000) and coral diseases (Francini-Filho et al. 2008) in reef ecosystems. Although the knowledge on the status of many Brazilian reef fish species has improved, the inclusion of such understanding in conservation status assessments and management strategies of reef fishes has been limited. Thus, it is important to identify differences between lists of threatened species and to understand how these differences might affect species conservation initiatives.
Moreover, it is essential to know how the current state of knowledge corresponds to the categorization of species at local scales if there are any management strategies for these species.

Reef fishes were defined as any shallow $(<100 \mathrm{~m})$ tropical/subtropical benthic or benthopelagic fishes that are associated with hard substrates of coral, algal, or rocky reefs or occupy adjacent sand substrate (i.e. use reef structures or surrounding areas for reproduction, feeding, and/or protection purposes). Based on this definition a database of reef fish species from the Brazilian Province was compiled (Floeter et al. 2008, A. Carvalho-Filho \& S. R. Floeter unpubl. data) generating a list of 559 reef fish species: 509 Teleostei and 50 Elasmobranchii (list available in Bender et al. 2012).

In the present paper we (1) identify, quantify and compare Brazilian reef fishes listed in different threatened species inventories, (2) indicate differences in species categorization and the criteria applied in these inventories and (3) discuss the implications of these differences between lists to the conservation of Brazilian reef fish threatened with extinction.

\section{MATERIALS AND METHODS}

\section{Compilation of red lists: dealing with differences in assessments}

The first step of this work involved compiling lists of reef fishes occurring in Brazil and mentioned by different threatened species inventories: the global IUCN Red List (IUCN 2011), national (MMA 2004, 2005a) and local (Brazilian states) red list assessments. The list which we compiled was based on lists which used IUCN categories and criteria (IUCN 2001, 2003) so as to enable comparisons among red lists at different spatial levels. This meant that we were able to use local inventories from the states of Espírito Santo (Vieira \& Gasparini 2007), Paraná (Mikich \& Bérnils 2004), Rio de Janeiro (Bergallo et al. 2000) and Rio Grande do Sul (Marques et al. 2002). The São Paulo state list (São Paulo 2008) could not be included in our comparisons since neither the categories nor criteria applied in its marine fish species evaluations correspond to those of the IUCN. On a regional level we also included information from the IUCN Workshop for Brazilian Epinephelinae and Lutjanidae Assessment (IUCN 2008).

The Brazilian Ministry of Environment (MMA 2004) defines a threatened species as that facing a 
risk of extinction in the near future, whereas an overexploited species is that in which populations are harvested at an unsustainable rate, reducing its biomass, spawning potential and catches. The National List of Threatened Aquatic Invertebrates and Fishes was published along with the Brazilian list of overexploited fishes, which categorizes 19 reef fish species as either overexploited or threatened with overexploitation (MMA 2004, 2005a). Since the set of categories and criteria utilized as guidelines in preparing this list are different from those of the IUCN (IUCN 2001, 2003), the Brazilian list of overexploited fishes was not included in our analysis.

The IUCN (IUCN 2001) considers as threatened species those listed under the Critically Endangered (CR), Endangered (EN) and Vulnerable (VU) categories. Species listed as Near Threatened (NT) and Least Concern (LC) are considered non-threatened, and Data Deficient (DD) are those taxa for which the currently available data do not allow their proper evaluation against IUCN criteria (as described in detail in IUCN 2001). Hereafter, we will refer to threatened species (CR, EN, or VU), and Near Threatened species (NT), following IUCN (2001).

\section{Comparing red lists}

After identifying Brazilian reef fish species listed as threatened at different scales by different red lists, the second step involved comparisons between the conservation statuses of species in those lists. Comparisons were made as follows: (1) threatened and non-threatened Brazilian reef fish species, where different threat level categories within those 2 groups were not considered, and (2) comparisons of threat categories to which endemic species were assigned in different lists (as either CR, EN, VU, NT, or LC). We applied binomial tests (Zar 2008) in order to verify if differences in the proportions of threatened or non-threatened species in compiled lists were significant. This analysis included only those species already evaluated against threat criteria. Of 559 reef fish species, 125 (22.3\%) were evaluated regarding their conservation status on different scales. Tests were performed using $\mathrm{R}$ software 2.14.2 (R Development Core Team 2012).

The qualitative analyses of red lists refer either to the total number of assessed reef fish species ( $\mathrm{n}=$ 125), the number of Elasmobranchii occurring in Brazil ( $\mathrm{n}=50)$, or the total number of Brazilian endemics ( $\mathrm{n}=68$; Carvalho-Filho unpubl. data). Finally, we discuss the implications of differences in reef fish species conservation status categories and the criteria applied in listing processes.

\section{RESULTS}

Forty-three reef fish species are listed as threatened with extinction $(34.4 \%, \mathrm{n}=125)$ (Table 1$)$. The IUCN Red List (IUCN 2011) lists 32 Brazilian reef fishes as globally threatened $(25.6 \%, \mathrm{n}=125)$, and $11(8.8 \%, \mathrm{n}=125)$ species are listed by the national and state inventories (Fig. 1). The difference in the proportions of species listed as threatened with extinction by global (IUCN) and national lists was significant ( $p<0.001)$, whereas national and local inventories were not significantly different from one another $(\mathrm{p}=0.831)$. A further 19 species $(15.2 \%, \mathrm{n}=$ 125) are categorized as NT by the IUCN (IUCN 2011), but national and state inventories do not categorize any species as NT.

Twenty-three bony reef fish species occurring in Brazil are at risk of extinction $(18.4 \%, \mathrm{n}=125)$. Although the number of threatened sharks and rays is smaller $(n=20)$, they represent $40 \%(n=50)$ of the Elasmobranch reef fauna that occurs in Brazil. Moreover, 15 shark and ray species are categorized as NT, meaning that $70 \%(n=50)$ of elasmobranchs utilizing reefs as habitat are either threatened or NT. Currently, $25.3 \%$ of Brazilian endemic reef fishes $(n=67)$ have been evaluated against red list criteria. Of these species, $8.9 \%(n=6)$ are threatened, and only 5 are cited in the global inventory. If we consider only those endemic species for which the conservation status has been assessed $(n=17)$, the proportion of threatened endemics reaches 35.2.

The categorization of reef fish species as threatened or not differs among the compiled lists (Table 1). Of 32 species listed as globally threatened, only 5 are mentioned by the national inventory. Four species are also listed as threatened by Espírito Santo state lists, 3 are threatened in Paraná, and 2 species in Rio Grande do Sul and Rio de Janeiro. The level of agreement between species on the global IUCN Red List and also on the national list is $15.2 \%$. In other words, $84.8 \%$ of the species listed by the IUCN do not appear on the national threatened species list. However, when it comes to species found on the Brazilian and on the IUCN lists, the level of agreement is $45.5 \%$. Eleven reef fish species are listed as threatened at the national scale, and 4 of those are also globally threatened. The concordance between fishes listed as threatened by the national assessment and state lists is $45.5 \%(\mathrm{n}=5)$ for Espírito Santo, 18\% 
Table 1. Reef fish species occurring in Brazil and categorized as 'threatened' by different red lists. IUCN: International Union for the Conservation of Nature (IUCN 2012); MMA: Brazilian Ministry of Environment (MMA 2004); ES: Espírito Santo (Vieira \& Gasparini 2007); PR: Paraná (Mikich \& Bérnils 2004); RJ: Rio de Janeiro (Bergallo et al. 2000); RS: Rio Grande do Sul (Fontana et al. 2003). Categorization for Tamandaré is taken from the IUCN Regional Workshop for the Evaluation of Brazilian Epinephelinae and Lutjanidadae, Tamandaré, Recife (2008). CR: Critically Endangered; EN: Endangered; VU: Vulnerable. Gaps indicate no data available

\begin{tabular}{|c|c|c|c|c|c|c|c|c|}
\hline Family & Species & IUCN & MMA & Tamandaré & ES & $\mathrm{PR}$ & RJ & $\mathrm{RS}$ \\
\hline Balistidae & Balistes vetula & VU & & & & & & \\
\hline Chaetodontidae & Prognathodes obliquus ${ }^{\mathrm{a}}$ & & VU & & & & & \\
\hline \multirow[t]{8}{*}{ Epinephelidae } & Epinephelus itajara & $\mathrm{CR}$ & $\mathrm{CR}$ & $\mathrm{CR}$ & EN & VU & & \\
\hline & Epinephelus morio & & & VU & & & & \\
\hline & Mycteroperca bonaci & & & VU & & & & \\
\hline & Mycteroperca interstitialis & VU & & VU & & & & \\
\hline & Epeniphelus marginatus & EN & & VU & & & & \\
\hline & Hyporthodus flavolimbatus & VU & & VU & & & & \\
\hline & Hyporthodus nigritus & CR & & $\mathrm{CR}$ & & & & \\
\hline & Hyporthodus niveatus & VU & & VU & & & & \\
\hline Gobiidae & Elacatinus figaro ${ }^{\mathrm{a}}$ & & VU & & VU & & & \\
\hline Grammatidae & Gramma brasiliensis $^{\mathrm{a}}$ & & VU & & VU & & & \\
\hline Haemulidae & Anisotremus moricandi & EN & & & & & & \\
\hline Labridae & Bodianus insularis & & VU & & & & & \\
\hline \multirow[t]{3}{*}{ Lutjanidae } & Lutjanus analis & VU & & & & & & \\
\hline & Lutjanus cyanopterus & VU & & VU & & & & \\
\hline & Lutjanus purpureus & & & EN & & & & \\
\hline Pomacentridae & Stegastes sanctipauli $^{\mathrm{a}}$ & VU & VU & & & & & \\
\hline Scaridae & Scarus trispinosus ${ }^{\mathrm{a}}$ & EN & & EN & & & & \\
\hline Serranidae & Anthias salmopunctatus ${ }^{\mathrm{a}}$ & VU & VU & & & & & \\
\hline Sparidae & Pagrus pagrus & EN & & & & & & \\
\hline \multirow{2}{*}{ Syngnathidae } & Hippocampus erectus & VU & & & VU & & VU & \\
\hline & Hippocampus reidi & & & & VU & VU & VU & \\
\hline Alopiidae & Alopias vulpinus & VU & & & & & & \\
\hline \multirow[t]{4}{*}{ Carcharhinidae } & Carcharhinus longimanus & VU & & & VU & & & \\
\hline & Carcharhinus obscurus & VU & & & & & & \\
\hline & Carcharhinus plumbeus & VU & & & & & & \\
\hline & Negaprion brevirostris & & VU & & & & & \\
\hline Ginglymostomatidae & Ginglymostoma cirratum & & VU & & VU & & & \\
\hline Gymnuridae & Gymnura altavela & VU & & & & & & \\
\hline Mobulidae & Manta birostris & VU & & & & & & \\
\hline Narcinidae & Narcine bancrofti & $\mathrm{CR}$ & & & & & & \\
\hline \multirow[t]{2}{*}{ Odontaspididae } & Carcharias taurus & VU & & & & & & VU \\
\hline & Odontaspis ferox & VU & & & & & & \\
\hline Rhincodontidae & Rhincodon typus & VU & VU & & VU & VU & & \\
\hline \multirow[t]{2}{*}{ Rhinobatidae } & Rhinobatos horkelii & $\mathrm{CR}$ & EN & & & & VU & VU \\
\hline & Zapteryx brevirostris & VU & & & & & & \\
\hline Rhinopteridae & Rhinoptera brasiliensis & EN & & & & & & \\
\hline \multirow[t]{4}{*}{ Sphyrnidae } & Sphyrna lewini & EN & & & & & & \\
\hline & Sphyrna mokarran & EN & & & & & & \\
\hline & Sphyrna tiburo & & & & VU & & & \\
\hline & Sphyrna zygaena & VU & & & & & & \\
\hline Squatinidae & Squatina punctata & EN & & & & & & \\
\hline
\end{tabular}

for Paraná $(n=2)$ and for Rio de Janeiro and Rio Grande do Sul only $9 \%(\mathrm{n}=1)$.

The IUCN Workshop for Brazilian Epinephelinae and Lutjanidae Assessment for 2008 listed 4 reef fish species as threatened: Epinephelus morio, Mycteroperca bonaci and Lutjanus purpureus as VU, and the Brazilian endemic Scarus trispinosus as EN (Ferreira et al. 2010, Comeros-Raynal et al. 2012). These spe- cies are not listed in any Brazilian inventories, either at a national or state scale.

In addition to disparities in species categorization as threatened or non-threatened, we came across differences regarding the levels of threat (CR, EN, VU) among Brazilian endemics listed as threatened with extinction. Two of the endemics listed as nationally threatened, Elacatinus figaro and Gramma brasilien- 


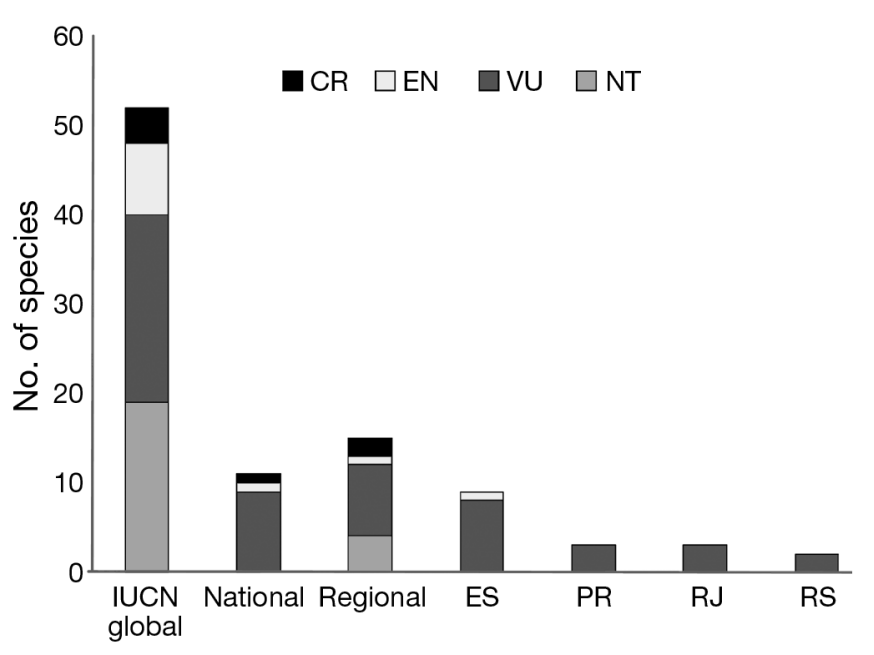

Red list

Fig. 1. Total number of reef fish species occurring in Brazil and listed as threatened (CR, EN, VU; see Table 1 legend) or Near Threatened (NT) in the IUCN Red List, the National MMA list, the IUCN regional evaluation, and Brazilian state lists: Espírito Santo (ES), Paraná (PR), Rio de Janeiro (RJ) and Rio Grande do Sul (RS)

sis (both VU), should be included in future reassessments of the global IUCN Red List. Both species are not mentioned in the global list. The Brazilian red list, in turn, does not mention Scarus trispinosus, categorized as EN by the IUCN Red List. Moreover, among local lists, only the Espirito Santo state list also considers the endemic species E. figaro and $G$. brasiliensis as VU. We discuss the possible reasons for mismatches in the following section.

\section{DISCUSSION}

Our findings reveal both agreements and differences among lists of threatened reef fish species. Although agreements have great value for increasing the credibility of red lists, these are especially important between national and local (state) lists, because at such scales inventories become official documents of legislation and implementation (Possingham et al. 2002). On the other hand, certain mismatches among species lists are counterproductive and can possibly undermine the credibility of red lists and hamper efforts in implementing specific management efforts for biodiversity conservation (Rodríguez et al. 2000, Brito et al. 2010, Helfman 2011).

Agreement can result from adherence to IUCN protocols or rank designations (Helfman 2011), even though it is recommended that local experts evaluate species status at the regional scale (IUCN 2003). Although there is high concordance in the categorization of terrestrial vertebrates between global and national lists (Brito et al. 2010), this is not the case for freshwater (Helfman 2011) and reef fishes (present study). The large proportion of reef fishes listed by the IUCN, but not mentioned in national lists, could be related to abundant local populations of globally threatened species (IUCN 2001). However, we do not believe that this is the case, given that some of those species were assessed as threatened at the national scale by experts at the regional IUCN workshop (see Table 1). The majority of such species have probably not been evaluated in the national listing process (missing species assessments, as pointed out by Helfman 2011). Some disagreements among lists are expected to occur (Brito et al. 2010), such as the listing of Bodianus insularis, Negaprion brevirostris and Ginglymostoma cirratum at the national level but not at the global scale. This simply reflects the higher risks faced by populations of those species at the evaluated scale. However, the non-listing of 2 Brazilian endemics represents a mistake in the global listing process, possibly attributed to the lack of communication among entities (Scarano \& Martinelli 2010, Helfman 2011).

We believe that disagreements in species lists could be a result of (1) an increase in species knowledge, leading to temporal changes in species categorizations, or (2) special interests that may influence species listing, such as the economic importance of fisheries. Greater scientific knowledge of species has led to temporal changes in species threat status in the IUCN Red List (Paglia \& Fonseca 2009); this could explain the listing mismatch of the endemic Prognathodes obliquus, threatened in the national list and globally DD. The interest in commercially important fish species might have altered the national red list, because its first version (MMA 2004) included Lutjanus analis, Carcharhinus porosus, C. signatus and C. longimanus as threatened, which were later removed from the list (MMA 2005b) without explanation.

In the case of endemics, global threat categories should be equivalent to those of the country in question (IUCN 2001). Therefore, the global IUCN Red List should list endemic reef fish species threatened at the national level, as is the case for Elacatimus figaro, Gramma brasiliensis and Prognathodes obliquus. A comparison between global and national lists for endemic taxa in South American countries (Bolivia, Argentina, Ecuador and Venezuela) showed that there is a trend in local assessments to incorpo- 
rate global data, whereas the opposite is less common (Rodríguez et al. 2000). The present study also revealed that among national endemic fishes listed as threatened none were mentioned by both global and national lists. Since 2001, the IUCN and other partner organizations have been expanding the geographic range of assessments for a number of taxa (amphibians, mammals, reptiles, marine and freshwater species and selected groups of plants), based on the contributions of experts from around the world (IUCN 2011). This action can improve the flow of information from a local to a global scale, increasing the accuracy of species' assessments. Local lists are especially important to increase the data availability of such large-scale evaluations of species conservation status (Rodríguez et al. 2000). Moreover, state lists can be considered a warning with respect to the local pressures faced by populations, as such state lists, when applied in the local management of threatened species, can prevent these species from also becoming threatened at a larger spatial scale. (Garcia \& Marini 2006). Thus, it is important that Brazilian state lists include assessments of fish species already listed in the national inventory (in states where the species occurs), in order to contribute to knowledge on species conservation status throughout the country and to guide conservation efforts.

The mismatches we identified for endemic species between local lists can be explained both by species distribution along the coast - most endemic species currently listed are restricted to Brazilian islands and a temporal factor - lists are published at different times. This temporal factor also explains the greater concordance of the Espírito Santo list with the Brazilian list, given that this state list was published $2 \mathrm{yr}$ after the national one. In future regional red listing processes, or species reassessments and list reviews, special attention should be given to those endemic species already listed as threatened, such as Elacatinus figaro, Gramma brasiliensis and Scarus trispinosus. Although endemic, these species have a fairly wide distribution along the coast; the first 2 are impacted by the ornamental trade and rendered vulnerable because of life-history traits (Gasparini et al. 2005, Bender et al. 2012), and the latter is overexploited by fisheries throughout its range (Floeter et al. 2006).

Mismatches related to the presence or absence of species from one list to another can have different consequences. Several reef fish species are listed as threatened at a global scale, but, despite being evaluated as regionally threatened (see Table 1), these species are not protected at a national scale. This is a serious problem for the conservation of populations of endemic species like Scarus trispinosus.

Another type of mismatch between lists is related to the set of categories and criteria applied in species assessments. In general, IUCN categories and criteria are used at the global scale, with adaptations to regional levels (IUCN 2003); this is not the case for all existent Brazilian lists. While the national list and the Paraná state list follow the regional adaptation of the IUCN categories and criteria (Gärdenfors et al. 2001), Espírito Santo and Rio de Janeiro lists are based on the IUCN categories and criteria Version 3.1. Although based on IUCN criteria, the São Paulo state list uses unique categories such as 'Collapsed', 'Overfished' and 'Threatened with overexploitation' for fish species (São Paulo 2008). In contrast, the Rio Grande do Sul list presents the IUCN threat categories, but the criteria underlying such categorizations are neither explicit nor transparent. Additionally, the publication of threatened species lists, along with a list of overexploited fish (e.g. national list and São Paulo state list) can affect the interpretation of these inventories, since the criteria applied vary among assessments and do not define the same type of risk.

Threatened species lists have become linked to decision-making processes, and in many countries there is a direct relationship between red lists and legislation. Despite being applied in different ways, the fundamental information transmitted by threatened species lists must be reliable (Possingham et al. 2002). It is important that the same set of categories and criteria are applied in order to enable (1) comparisons of conservation status among species in different locations and/or at different geographical scales, recovery of threatened species, the effectiveness of public policies in species management and conservation across several states; (2) compilations and evaluations of species conservation status at the national level; and (3) compilation of candidate species to be assessed in other evaluations.

Even though the Brazilian list of threatened fish was published in 2004 (MMA 2004, 2005a), strategies to support the recovery of endangered and overexploited species have not been defined yet. Despite the 5 yr period set by the Brazilian Ministry of Environment for the preparation of management plans for such species (MMA 2004), funding for appropriate actions has never been made available. In 2006, the ministry announced a call for plan proposals (MMA 2006), but apparently this effort did not continue. These plans are essential to reduce the extinction risk of threatened species. Capture of 
the 11 reef fish species listed as nationally threatened is prohibited along the Brazilian coast (MMA 2004). The Epinephelidae species Mycteroperca bonaci and Epinephelus marginatus were evaluated as threatened in the regional IUCN workshop. Along certain parts of the Brazilian coast there are fishing restrictions on the size of $M$. bonaci and $E$. marginatus individuals which may be captured (MMA 2005b); however, this management strategy is not related to the species' listing as imperiled. For elasmobranchs, a conservation action plan was developed by the Brazilian Society of Elasmobranch Studies, independently of the Brazilian authorities (Lessa et al. 2005). Continuity in species management and conservation processes has been sadly neglected by Brazilian decision makers, and greater pressure is now required from the scientific community. Another important step that has already been taken by the environmental ministry is the updating of the current list of threatened marine fish, extending the evaluation to other species.

Strategies to enhance the level of agreement between red lists include: improved communication, better institutional support for listing efforts, mediated conflict resolution and recognition of the value of diverse listing efforts (Helfman 2011). It is also important that environmental agencies and those agencies providing financial support to species evaluation and listing processes are closely linked, not only at a local but also at a national level. Actions for the protection and recovery of threatened species usually occur within the borders of countries and are frequently based on documents such as red lists. Therefore, those involved in species evaluations and listing processes must be aware of the causes and consequences of mismatches between threatened species lists.

Acknowledgements. Comments by J. L. Gasparini, M. Cantor, F. Vieira, A. Carvalho-Filho and 2 referees greatly improved earlier versions of this manuscript. M.G.B. thanks M. Brick Peres for encouraging this work.

\section{LITERATURE CITED}

> Akçakaya HR, Ferson S, Burgman MA, Keith DA, Mace GM, Todd CR (2000) Making consistent IUCN classifications under uncertainty. Conserv Biol 14:1001-1013

Becker CG, Loyola RL (2008) Extinction risk assessments at the population and species level: implications for amphibian conservation. Biodivers Conserv 17:2297-2304

Bender MG, Floeter SR, Mayer F, Vila-Nova DA and others (in press) Biological attributes and major threats as predictors of species' vulnerability: a case study with Brazilian reef fishes. Oryx
Bergallo HG, Rocha CFD, Alves MAS, Van Sluys M (organisers) (2000) A fauna ameaçada de extinção no estado do Rio de Janeiro. EdueRJ, Rio de Janeiro

Brito D, Ambal RG, Brooks T, De Silva N and others (2010) How similar are national red lists and the IUCN Red List? Biol Conserv 143:1154-1158

Comeros-Raynal MT, Choat JH, Polidoro BA, Clements KD and others (2012) The likelihood of extinction of iconic and dominant herbivores and detritivores of coral reefs: the parrotfishes and surgeonfishes. PLoS ONE 7: e39825

Craig, MT, Sadovy de Mitcheson YJ, Heemstra PC (2011) Groupers of the world: a field and market guide. NISC, Grahamstown

Ferreira CEL, Gonçalves JEA (1999) The unique Abrolhos reef formation (Brazil): need for specific management strategies. Coral Reefs 18:352

Ferreira BP, Floeter SR, Rocha LA, Ferreira CEL and others (2010) Scarus trispinosus. In: IUCN 2011. IUCN Red List of threatened species, Version 2011.2. Available at: www. iucnredlist.org/details/summary/190748/0 (accessed on 25 Nov 2011)

Floeter SR, Halpern BS, Ferreira CEL (2006) Effects of fishing and protection on Brazilian reef fishes. Biol Conserv 128:391-402

Floeter SR, Rocha LA, Robertson DR, Joyeux JC and others (2008) Atlantic reef fish biogeography and evolution. J Biogeogr 35:22-47

Fontana CS, Bencke GA, Reis RE (eds) (2003) Livro vermelho da fauna ameaçada de extinção no Rio Grande do Sul. Decreto No. 41.672, EDIPUCRS, Porto Alegre, RS

Francini-Filho RB, Moura RL (2008) Dynamics of fish assemblages on coral reefs subjected to different management regimes in the Abrolhos Bank, eastern Brazil. Aquat Conserv 18:1166-1179

> Francini-Filho RB, Moura RL, Thompson FL, Reis RD, Kaufman L, Kikuchi RKP, Leão ZMAN (2008) Diseases leading to accelerated decline of reef corals in the largest South Atlantic reef complex (Abrolhos Bank, eastern Brazil). Mar Pollut Bull 56:1008-1014

Garcia FI, Marini MA(2006) Estudo comparativo entre as listas global, nacional e estaduais de aves ameaçadas no Brasil. Nat Conservação 4:24-49

Gärdenfors U (2001) Classifying threatened species at the national versus global levels. Trends Ecol Evol 16: 511-516

> Gärdenfors U, Hilton-Taylor C, Mace GM, Rodríguez JP (2001) The application of IUCN Red list criteria at regional levels. Conserv Biol 15:1206-1212

Gasparini JL, Floeter SR, Ferreira CEL, Sazima I (2005) Marine ornamental trade in Brazil. Biodivers Conserv 14: 2883-2899

Helfman GS (2011) National 'versus' global red lists of imperiled fishes: Why they discord? Environ Biol Fish. doi: 10.1007/s10641-011-9843-x

> Hilton-Taylor C, Mace GM, Capper DR, Collar NJ and others (2000) Assessment mismatches must be sorted out: They leave species at risk. Nature 404:541

IUCN (International Union for Conservation of Nature) (2001) IUCN Red List categories and criteria, Version 3.1. IUCN, Gland

IUCN (International Union for Conservation of Nature) (2003) Guidelines for application of IUCN Red List criteria at regional levels, Version 3.0. IUCN, Gland

IUCN (International Union for Conservation of Nature) (2008) IUCN regional workshop for the evaluation of 
Brazilian Epinephelinae and Lutjanidadae. Tamandaré, Recife

IUCN (International Union for Conservation of Nature) (2011) The IUCN Red List of threatened species, Version 2011.2. Available at: www.iucnredlist.org (accessed 10 November 2011)

Keller V, Bollmann K (2004) From Red Lists to species of conservation concern. Conserv Biol 18:1636-1644

Lamoreux J, Akçakaya HR, Bennun L, Collar NJ and others (2003) Value of the IUCN Red List. Trends Ecol Evol 18: 214-215

Leão ZMAN, Dominguez JM (2000) Tropical coast of Brazil. Mar Pollut Bull 41:112-122

Lessa R, Vooren CM, Araújo MLG, Kotas JE and others (2005) Plano nacional de ação para a conservação e o manejo dos estoques de peixes Elasmobrânquios no Brasil. Sociedade Brasileira para estudos de Elasmobrânquios, Recife

Mace GM, Lande R (1991) Assessing extinction threats: toward a revaluation of IUCN threatened species categories. Conserv Biol 5:148-157

Marques AAB, Fontana CS, Vélez E, Bencke GA, Scheneider M, dos Reis RE (2002) Lista das espécies da fauna ameaçadasde extinção no Rio Grande do Sul. Decreto 41.672, FZB/MCT-PUCRS/PANGEA, Porto Alegre

Mikich SB, Bérnils RS (2004) Livro vermelho da fauna ameaçada no estado do Paraná. Instituto Ambiental do Paraná, Curitiba. Available at: www.iap.pr.gov.br/ (accessed 12 January 2012)

Miller RM, Rodríguez JP, Aniskowicz-Fowler T, Bambaradeniya $C$ and others (2006) Extinction risk and conservation priorities. Science 313:441

Miller RM, Rodríguez JP, Aniskowicz-Fowler T, Bambaradeniya $C$ and others (2007) National threatened species listing based on IUCN criteria and regional guidelines: current status and future perspectives. Conserv Biol 21:684-696

MMA (Ministério do Meio Ambiente) (2004) Lista Nacional das Espécies de Invertebrados Aquáticos e Peixes ameaçados de extinção com categorias da IUCN. Instrução Normativa No. 5 de 21 maio de 2004, Brasília. www. mma.gov.br/apoio-a-projetos/fundo-nacional-do-meioambiente/editais-e-termos-de-referencia/item/334

MMA (Ministério do Meio Ambiente) (2005a) Alteração da Instrução Normativa No. 5, de 21 de maio de 2004. Instrução Normativa No. 52 de 8 de outubro de 2005, Diário Oficial da União, Brasília

Editorial responsibility: Steven Cooke, Ottawa, Ontario, Canada
MMA (Ministério do Meio Ambiente) (2005b) Tamanho mínimo para captura de espécies marinhas e estuarinas do litoral sul e sudeste do Brasil. Instrução Normativa No. 53, 22 de novembro de 2005, Diário Oficial da União, Brasília

MMA (Ministério do Meio Ambiente) (2006) Edital FNMA No. 02 de abril de 2006 voltado à 'Elaboração de Planos de Recuperação e de Gestão de Espécies de Peixes e Invertebrados Aquáticos'. Brasília

Paglia AP, Fonseca GAB (2009) Assessing changes in the conservation status of threatened Brazilian vertebrates. Biodivers Conserv 18:3563-3577

> Possingham HP, Andelman SJ, Burgman MA, Medellín RA, Master LL, Keith DA (2002) Limits to the use of threatened species lists. Trends Ecol Evol 17:503-507

R Development Core Team (2012) R: a language and environment for statistical computing. R Foundation for Statistical Computing, Vienna

Rodrigues ASL, Pilgrim JD, Lamoreux JF, Hoffmann M, Brooks TM (2006) The value of the IUCN Red List for conservation. Trends Ecol Evol 21:71-76

Rodríguez JP, Ashenfelter G, Rojas-Suárez F, García-Fernández JJ, Suárez L, Dobson AP (2000) Local data are vital to worldwide conservation. Nature 403:241

São Paulo (2008) Lista da fauna silvestre ameaçada de extinção no estado de São Paulo. Decreto No. 53.494, Diário Oficial do Estado de São Paulo, Seção 1, 118

> Scarano FR, Martinelli G (2010) Brazilian list of threatened plant species: Reconciling scientific uncertainty and political decision-making. Nat Conservação 8: $13-18$

Vieira F, Gasparini JL (2007) Os peixes ameaçados de extinção no estado do Espírito Santo. In: Passamani M, Mendes SR (eds) Espécies da fauna ameaçadas de extinção no estado do Espírito Santo. Instituto de pesquisas da Mata Atlântica (Ipema), Vitória

- Vila-Nova DA, Bender MG, Carvalho-Filho A, Ferreira CEL, Floeter SR (2011) The use of non-reef habitats by Brazilian reef fish species: considerations for the design of Marine Protected Areas. Nat Conservação 9: 79-86

von May R, Catenazzi A, Angulo A, Brown JL and others (2008) Current state of conservation knowledge on threatened amphibian species in Peru. Trop Conserv Sci 1:397-416

Zar JH (2008) Biostatistical analysis, 5th edn. Pearson Prentice Hall, Englewood Cliffs, NJ

Submitted: January 18, 2012; Accepted: July 10, 2012

Proofs received from author(s): September 10, 2012 